\title{
Cutback Management in the United Kingdom: Challenges of Fiscal Consolidation for the Administrative System*
}

\author{
Stephen Wilks**
}

\begin{abstract}
This article reviews the administrative implications of the fiscal gap that has opened up in all OECD countries as a result of the financial crisis. It outlines the pressures for fiscal consolidation, which will lead to deep and prolonged real cuts in public spending. The article examines the political debate in the United Kingdom and stresses the exceptional difficulties facing all administrative systems over what might be a decade of spending restraint. Accordingly, it anticipates an emphasis on "cutback management" as last seen in the United Kingdom in the 1980s, and reflects on the successful Canadian experience. Three hypotheses are advanced: failure to control spending; success based on the New Public Management; and the need to adapt government capabilities to manage cutbacks. Implementing large real cuts in the face of political and administrative pressures for budget maximization will require extraordinary political determination. Intelligent and constructive definition and implementation of spending priorities will require a reconfiguration of administrative systems, which may amount to a new paradigm.
\end{abstract}

Keywords: cutback management, fiscal consolidation, budgeting, administrative reform

\section{THE GLOBAL PANDEMIC OF FISCAL CONSOLIDATION}

It has become an overworked cliche to observe that "when America sneezes, Europe catches the cold." Nonetheless, this echo of the 1929 stock market crash presents a nice image of contagion, and we have seen that when America goes into recession, Europe

* An early draft of this paper was given at the Korea Institute of Public Administration (KIPA) Conference in Seoul in October 2009. The author is grateful for the support of KIPA and the comments of Bruce Doern, Exeter; Jon Pierre, Gothenburg; and Joong-hoon Park, KIPA. He acknowledges the financial support of the EU Garnet Network.

** Stephen Wilks is Professor of Politics at the University of Exeter. He is currently working on a book on the political power of the business corporation. Email: s.r.m.wilks@exeter.ac.uk.

Manuscript received February 20, 2010; out for review March 8, 21010; review completed April 15, 2010; accepted April 18, 2010.

The Korean Journal of Policy Studies, Vol. 25, No. 1, 85-108 (2010)

(C) 2010 by the GSPA, Seoul National University 
and Asia have to fight to avoid depression. But as with so many economic trends, the U.S. financial crisis was also a British financial crisis. It appeared initially as a crisis generated by the free-wheeling free-market capitalism that the French and the Germans are apt to criticize as the "Anglo-Saxon model" of an individualistic liberal market, driven by market signals and energized by greed. Accordingly, the early responses in continental Europe could be captured by that wonderful German word Schadenfreude, which roughly translates as delight in the misfortune of others. This seemed to be a crisis of neoliberal capitalism and to signify a swing in the pendulum of economic fashion away from the Thatcher/Reagan prescriptions of unleashed markets and back to the more sober, coordinated, and solidaristic models found in Germany or Japan.

Unfortunately, the financial crisis metamorphosed into a global economic crisis, with spectacular falls in economic activity during 2008 and a fall in export demand and trade that hit the big exporting countries of Germany, Japan, and China especially hard. We have experienced a synchronized global recession, which appears singularly unfair to those countries with responsible financial systems and conservative lending practices.

The response to the economic crisis has been a return to strong interventionist government, which has also been partially globally synchronized through the G-20. Monetary policy instruments of low interest rates and credit easing failed to give traction, so governments turned to fiscal policy and to Keynesian solutions. This was, in Skidelsky's words, The Return of the Master (Skidelsky 2009), and governments have injected vast resources into financial, product, and consumer markets in order to prevent the recession from turning into a depression.

The outcome has been a huge fiscal gap between falling revenue and rising expenditure, bringing a stunning increase in government borrowing, a rapidly rising projection of government debt, and a disgraceful socialization of private debt with highly controversial transfers of costs from bankers and property owners to the state. This has precipitated a rerun of history. The cycles of capitalism have taken us "back to the future," and the United Kingdom, like all European countries, is facing a "fiscal crisis of the state" with sinister echoes of the late 1970s (O'Connor 1973).

The global recession and the fiscal crisis have momentous implications for the role of government, the design and intensity of regulation, the tension between globalization and the nation-state, and choices about the most desirable variant of the capitalist model. This article is concerned with a more focused issue, public administration in an age of austerity or scarcity. In another echo of the late 1970s, "cutback management" is back on the agenda (see Dunsire and Hood 1989).

The impending age of austerity can be captured in the modest but threatening phrase "fiscal consolidation"-in other words, efforts to cap, and eventually to reduce, 
the unprecedented increase in government debt. One measure of the terrifying scale of the fiscal catastrophe that confronts most governments is debt as a percentage of GDP. Table 1 indicates that no OECD country has escaped a huge deterioration in public finances but that some are in a far worse absolute position than others. Compared with historic expectations that a deficit of 3 percent of GDP was excessively high (this was the limit in the euro zone before the crisis), the recent Irish, British, and U.S. doubledigit borrowing appears unsustainable.

Table 1. Government Deficits as a Percentage of GDP

\begin{tabular}{lrcc}
\hline & 2007 & 2010 & Deterioration \\
\hline Korea & +4.7 & -2.3 & 7.0 \\
Italy & -1.5 & -5.8 & 4.3 \\
Canada & +1.6 & -5.9 & 7.5 \\
Germany & 0.2 & -6.2 & 6.0 \\
France & -2.7 & -7.9 & 5.2 \\
J apan & -2.5 & -8.7 & 6.2 \\
USA & -2.9 & -11.2 & 8.3 \\
Ireland & +0.2 & -13.6 & 13.8 \\
UK & -2.7 & -14.0 & 11.3 \\
Euro zone & -0.7 & -7.0 & 6.3 \\
All OECD & -1.4 & -8.8 & 7.4 \\
\hline
\end{tabular}

Note: Countries are ranked in order of 2010 debt. Annual fiscal surplus (+) or deficit (-) is given as a percentage of GDP. Source: OECD, Economic Outlook 85, J une 2009, Table 4.4, 231.

Under these circumstances, with an eye to reassuring international credit markets, governments have announced plans to embark on fiscal consolidation by closing the annual spending gap and reducing the long-term debt burden. The OECD has classified consolidation plans into three categories: countries that do not need to consolidate, those assumed to consolidate over three years, and those assumed to consolidate over seven years. Table 2 presents the classification of nine sample countries.

All countries listed in the table face fiscal pressure, but the worst problems are faced by Ireland, the United States, and the United Kingdom. Fiscal consolidation can be achieved by increasing revenue (raising taxes), cutting expenditures, or both. In practice, expenditure cuts are likely to bear the brunt of the reduction. How times have changed!

The United Kingdom, like virtually all OECD countries, has enjoyed a decade of prosperity and steady growth, which Mervyn King, the governor of the Bank of England, first referred to in 2003 as the NICE years (Non-Inflationary Continuous Expansion). In the last seven years, public expenditure in the United Kingdom, as a percent- 
Table 2. Fiscal Consolidation Plans by Percentage of GDP

\begin{tabular}{|c|c|c|c|c|}
\hline & \multirow{2}{*}{$\begin{array}{c}\begin{array}{c}\text { Assumed } \\
\text { consolidation }\end{array} \\
2010-17 \\
\end{array}$} & \multicolumn{3}{|c|}{$\begin{array}{c}\text { Gross financial liabilities } \\
\text { (\% of GDP) }\end{array}$} \\
\hline & & 2007 & 2010 & 2017 \\
\hline \multicolumn{5}{|c|}{ No exceptional consolidation } \\
\hline Korea & 1.2 & 26 & 39 & 49 \\
\hline \multicolumn{5}{|c|}{ Consolidation over three years } \\
\hline Canada & 5.0 & 64 & 82 & 67 \\
\hline Germany & 4.7 & 65 & 84 & 71 \\
\hline France & 3.2 & 70 & 94 & 99 \\
\hline Italy & 3.0 & 112 & 127 & 112 \\
\hline Japan & 4.2 & 167 & 200 & 208 \\
\hline \multicolumn{5}{|c|}{ Consolidation over seven years } \\
\hline United States & 9.4 & 63 & 98 & 103 \\
\hline Ireland & 7.0 & 28 & 80 & 125 \\
\hline United Kingdom & 7.1 & 47 & 89 & 125 \\
\hline Euro zone & & 71 & 89 & 85 \\
\hline All OECD & & 74 & 100 & 104 \\
\hline
\end{tabular}

Source: OECD, Economic Outlook 85, J une 2009, Table 4.4, 231.

Note: The "assumed consolidation" figure is an OECD estimate based on removal of fiscal stimulus spending followed by a saving of 1 percent of GDP every year for zero, three, or seven years. The gross financial liabilities represent the projected overall government debt burden as a percentage of GDP if consolidation is successful.

age of GDP (which was itself rising), rose from 36.3 in 1999-2000 to 41 in 2007-08 (Treasury 2009a, 65, Table 4.1). But to cite the Bible (Genesis 41: 29-31): "There came seven years of great plenty throughout the land. . . And there shall arise after them seven lean years of famine; and all the plenty shall be forgotten. . . . It shall be very grievous." It does look as if the United Kingdom, among others, is facing seven lean years. But while Pharaoh took Joseph's sage advice and put aside reserves for the lean years, the United Kingdom's administrative systems have no reserves to draw upon and face a truly grievous level of threatened cuts that has not been seen since the 1920s.

In this setting, the whole focus of British politics has shifted, to a remarkable degree, to fiscal policy. This reflects a renewed emphasis on economic policy in a recession but also the coincidence of the economic and the political cycles. At the time of writing, Gordon Brown's Labor government was fighting a general election to be held on May 6, 2010, and the campaign is revolving around options for public spending cuts. Inescapably, the election will be determined by the state of the economy, how the financial crisis has been managed, and the credibility of proposals for dealing with 
the aftermath and achieving a robust recovery. The Conservative opposition has managed to move the debate beyond market failure and away from questions of bankers' greed, regulatory failure, and redesign of the economic model onto public debt and fiscal policy — specifically, how quickly the debt should be reduced, whether this should be achieved by increased taxes or decreased spending, and which taxes or cuts are most desirable.

This is not only a technical debate; it has become very political and ideological. The big question concerns the size and role of the state. In the wake of market failure, should the state become more active? Britain's finance minister, Alistair Darling, has expressed Labour's case for an activist, enabling state, remarking that "people rightly talk about the invisible hand of the market, but it goes alongside the enabling hand of government" and arguing that "the global recession and the global response to tackle it have demonstrated the difference that strong, active government can make" (Darling 2009, 5). The Conservatives, under David Cameron, who polls show are likely to win the election, are more skeptical of the enlarged state. They argue for a reduction in the burdens on business, cuts in the public sector, and a fierce regime of expenditure reductions rather than tax increases. In short, the debate is repeating many of the arguments of the 1970s and early 1980s, when Margaret Thatcher's attack on a bloated, inefficient public sector ushered in two decades of neoliberal policy and relaxed regulation.

Whoever wins the UK election, there will be historically unprecedented cuts in public spending. This paper examines the implications of those cuts for public administration from four perspectives: the timing and scale of the cuts, the political debate, administration under scarcity, and the strategy and tactics of spending cuts. It concentrates on the United Kingdom, partly because of space constraints but also because the UK situation is one of the most serious and because, in this area of national spending, Europe is disaggregated.

In relation to fiscal policy and public spending, the countries in the euro zone have to operate within macroeconomic policy constraints, but the details of spending programs are still nationally determined. The EU Stability and Growth Pact requires EU members to limit their budget deficits to 3 percent of GDP, but this applies with more force to the members of the euro zone; and in any case, even before the recession, the rules had been breached sufficiently often to call into question the credibility of the Pact (Fingland and Bailey 2008). As a spending authority, the EU is virtually irrelevant. It is famously a "regulatory polity" with trivial revenues, a small amount of integrationist spending, and a tiny bureaucracy. This may be beginning to change in relation to the euro zone, where huge budget deficits prejudice the credit rating of individual countries and, by limiting their ability to borrow, threaten to destroy the integrity of the euro. 
This specter of possible defaults on sovereign debt became an issue at the beginning of 2010 with the revelation that the Greek budget deficit had been concealed. The new government of George Papandreou admitted that, instead of a deficit of 3.7 percent, the real deficit for 2009 was nearer to 12.7 percent. Attempts to cut the deficit have already provoked civil unrest and public sector strikes. All this has alarmed the financial markets and threatened a downgrade by the credit rating agencies that would have pushed up Greek government borrowing costs to penal levels (Smith 2010). At the time of writing, an EU-coordinated financial rescue package was being debated under the threat that a Greek default would inevitably shift the focus of the financial markets to other highly indebted European countries, including Ireland, Portugal, Spain, and Italy.

For the argument advanced here, the key factor is the need to establish credibility in international bond markets. Since the UK deficit for 2009-10 is, at 12.6 percent, almost exactly the same as that of Greece, it is not difficult to see the danger to the United Kingdom's creditworthiness. This ramps up the pressure for UK fiscal consolidation, but it does so through the politically objectionable and morally dubious vehicle of the international financial markets, precisely the agencies that created the problems in the first place.

\section{THE TIMING AND SCALE OF SPENDING CUTS}

In the public sector, 2009 had the air of a phony war or the calm before the storm. Although the Treasury is budgeting for cuts, they will not begin to bite until the middle of 2010. The posture of the finance minister has been like that of St. Augustine, who asked God to give him chastity and continence, but not to give them yet; he and the prime minister have been adamant that cuts should not be implemented until the economic recovery is clearly established. The fear of prejudicing the recovery by early budget cuts is shared by most economists, but there is also an argument on the left and among the unions that deep cuts are not necessary and are pandering to a right-wing agenda.

The left and the unions argue that governments are not like households, that the Keynesian magic should be allowed to work, that in a low-inflation, low-interest environment public debt is easy to finance and, in any case, that total UK debt is not excessive by international standards. This provides an important political context, because it will cast doubt on the legitimacy of the deep cuts that politicians have proposed, and it will reinforce the confrontational arguments of public sector unions, which are far more concerned with the failure of markets, excessive financial remuneration, and 
inequality and unemployment than they are with the size of public debt. Prime Minister Gordon Brown appears sympathetic to this perspective. He has argued strongly in European and international arenas that coordinated fiscal stimulus should be sustained, and he could not bring himself even to utter the word "cuts" until September 2009, when it appeared in a speech to the Trades Union Congress.

Despite this hesitation, the green shoots of recovery will expose the spending deficits to the frost of budget cuts. The United Kingdom technically emerged from recession in the fourth quarter of 2009 , and as soon as stable growth is resumed, the government will have to reduce expenditures. This section reviews the likely scale of this fiscal retrenchment.

The British government plans expenditure over a three-year planning horizon, so that spending plans published in November 2008 outlined spending for the years 2009-10 to 2011-12. The 2008 plans forecast an annual borrowing requirement of $£ 175$ billion for $2009-10$, which is 12.4 percent of GDP. They outline the intention to reduce borrowing over eight years with a final target of $£ 90$ billion a year or 6.4 percent of national income (IFS 2009b, 2). Through a combination of tax increases and spending reductions, this would eliminate the structural budget deficit. The Treasury plans anticipate that half that reduction would take place over the four years 2010-11 to 2013-14.

The reduction would be dominated by spending cuts, so that 20 percent of it would be achieved by tax increases, 30 percent by cuts in capital spending, and the remaining 50 percent by cuts in current spending. The Institute for Fiscal Studies (IFS) has calculated that the cuts, at constant prices adjusting for inflation, over the three years 201112 to 2013-14, will reduce capital spending by 17.5 percent and increase current spending by 0.7 percent, cutting total expenditure by a mere 0.1 percent. That appears modest and relatively painless, but it understates the administrative challenge and vastly understates the scale of the likely cuts, for three reasons.

First, the government divides spending into the categories of departmental expenditure limits (DELs), which represent controllable spending, and annually managed expenditure (AME), which is demand-led and not subject to annual control, such as social security benefits and debt interest (see table 3 ).

Table 3. Planned Public Spending for 2009-2010

\begin{tabular}{lr}
\hline DELS (departmental expenditure limits) & $£ 342.1$ billion \\
AME (annually managed expenditure) & $£ 265.9$ billion \\
Capital spending & $f 63.4$ billion \\
Total managed expenditure & $\mathrm{f} 671.4$ billion \\
\hline
\end{tabular}

Source: Treasury 2009b, 26. 
Internal Treasury forecasts leaked to the press in September 2009 showed that the Treasury expects substantial real increases in debt servicing costs and social security spending. This increases the AME spending and puts far greater pressure on the controllable DEL spending. As a result, the IFS observed that "this would be the tightest squeeze in spending on public services since the UK was negotiating its spending plan with the International Monetary Fund in the late 1970s" (IFS 2009b, 32).

Second, some public services may be protected from cuts. The Labor government has undertaken to protect the National Health Service (NHS), schools, and international aid. Since the annual DEL of the NHS is around $£ 73$ billion, the other DEL spending categories will need to be cut even deeper, by an amount that the IFS calculates at a massive 12.9 percent over the two years 2011-12 and 2012-13 (IFS 2010, S7).

Third, the government estimates were almost certainly too optimistic. They included, for instance, $£ 9$ billion of "efficiency savings" to be achieved by 2013-14, but the details remain hazy. Equally optimistically, the plan assumed the resumption of economic growth rising to at least 3.5 percent beginning in 2011-12 and continuing at that level (Treasury 2009b, 2).

Overall, the IFS's understated conclusion that "whichever scenario you look at, public spending seems set for a protracted squeeze" appears correct. The enormity of that squeeze is further underlined by the conclusion that "much of the rise in spending on public services under Labor looks set to be reversed" (IFS 2009b, 33, 34). This is a defining moment or, for historical institutionalists, a "critical juncture" (Hall and Taylor 1996, 942). Ten years worth of policy initiatives, spending aspirations, and service growth are going to be put into reverse. Where will the cuts fall? And how is the civil service going to deliver those cuts? Self-mutilation is an unattractive prospect.

\section{THE POLITICAL DEBATE}

Decisions about spending priorities are by definition political, but the whole debate in Britain had become highly politicized by the autumn of 2009. Politicians have come to recognize, in the words of a respected Liberal Democrat, that "the central issue emerging now in the UK-and the one which will dominate politics for the next few years - is the size of the UK government budget borrowing and deficits, and government debt" (Cable 2009, 5). The spending debate has been seized upon by the opposition parties and has become quickly absorbed into adversarial party politics that, again, has echoes of the 1970s and 1980s. The political parties find the debate convenient because it can settle nicely into traditional class ideologies, offers endless possibilities for point scoring, and provides a battleground for the 2010 election and material for the 
party manifestos with which parties seek to attract voters.

Based on the early skirmishes in this spending battle, a series of fault lines have begun to emerge that help to differentiate the policies of the main parties and the spending choices that will confront the administrative machine. The most contested issues are (1) tax increases versus spending cuts, (2) big government versus small government, (3) evaluation of the public sector, (4) management of the recovery, and (5) whether to see the crisis as an opportunity for radical initiatives.

Tax increases versus spending cuts: The question of whether to secure fiscal consolidation mainly by increasing taxes or by cutting spending is a classic left/right debate, with the left certain to emphasize progressive tax increases. One highly perceptive analysis by Giles Wilkes (2009) has provided ammunition for both sides. Wilkes pointed out that the United Kingdom's extraordinary fiscal deterioration is not due to recessionary spending but to an amazing collapse in revenues. The tax yield was artificially inflated by credit bubbles, which boosted corporate, property, and income taxes that have now evaporated. He broke down the causes of government debt as shown in table 4.

Table 4. Causes of UK Government Debt in 2012-2013

\begin{tabular}{lc}
\hline Cause & Percentage \\
\hline Recessionary spending & 4 \\
Banking rescues & 9 \\
Loss of "bubble" revenues & 9 \\
Preexisting structural gap & 16 \\
Loss of revenues & 25 \\
"Normal" borrowing & 37 \\
Total debt & 100 \\
\hline
\end{tabular}

Source: Wilkes 2009, 38.

This analysis suggests that it would be very difficult to rebuild the tax base. However, Wilkes went on to argue in favor of property taxes directed at housing by abolishing the family home exemption from the capital gains tax or introducing a levy on expensive housing (the so-called mansion tax). He argued that this would be equitable and would have a minimal impact on entrepreneurship and growth because it would not tax economic activity.

Big or small government: The financial crisis has clearly reinvigorated the debate about public versus private, state versus market, the benefits of state intervention, and the prospects for a new version of the New Deal (Gamble 2010,13). The crisis should arguably have finally laid to rest the "end of history" Reagan/Thatcher consensus that 
government is malign and that the market provides freedom and prosperity. Yet the critics of big government and the defenders of market freedom are renewing their critique of the state, and Labor has been slow to assert governmental authority. Gordon Brown's government has appeared weak in its approach to intensified financial regulation and the lightning rod issue of excessive bankers' bonuses. In fearsome rhetoric, and echoing the analysis of former International Monetary Fund chief economist Simon Johnson (2009), Monbiot said that "the political establishment in is thrall to the financial establishment. . . . to sustain this parasitic industry every other sector must be cut" (Monbiot 2009). In particular, the government is a reluctant owner of a large section of the banking sector but appears wholly unwilling to deploy its ownership rights.

Despite their reluctance to confront the banks, the finance minister and other senior ministers have affirmed the benefits of an active interventionist state. Indeed, Gordon Brown's main claim to electoral support is his role in responding boldly and assertively to the financial crisis and playing a global leadership role praised by many, including the Nobel laureate Paul Krugman (2008). Brown's most powerful minister, the business secretary, Lord Peter Mandelson, has declared:

We reject the argument of those on the right who argue that the state is an obstacle to human freedom. ... The big success story of British social democracy in the last twelve years has been the rescue, revival and rehabilitation of public services (Mandelson 2009).

It might be expected that the pendulum of administrative fashion would be swinging back towards a larger, more interventionist role for government.

Evaluation of the public sector: Despite the defects in private sector markets and the credit bubbles that created the financial crisis, politicians and the media continue to express resentment towards the public sector, which is perceived to be too large and to have overly generous employment conditions, including noncontributory or subsidized pensions. Moreover, the increases in public spending over the last ten years have not increased public sector productivity. One theme of spending reduction is therefore to target the workforce through cuts in numbers, cuts in pension entitlements and, especially popular, a public sector pay freeze combined with pay cuts for the most senior public sector managers.

Defenders of public sector employees point out that most of them are poorly paid and deserve some job security in compensation. This argument is made forcibly by public sector unions such as Unison. Although union power in the United Kingdom has weakened markedly since the 1980s, the public sector is still strongly unionized (59 percent against only 17 percent in the private sector-DTI 2006), and cuts will 
almost certainly bring strikes and industrial actions.

Management of the recovery: The reflex assumption in the debate about cuts is that they should not inhibit the resumption of substantial and sustained economic growth. During the election campaign, the need to postpone cuts in order to sustain the recovery became a central plank in Gordon Brown's campaign rhetoric. This basic Keynesian tactic is, of course, inconsistent with the pre-2008 neoliberal policy stance that growth requires a reduction in state spending, regulation, and intervention. Such neoliberal assumptions were too embedded to be abandoned easily, but they were tempered by the new popularity of Keynesian intervention, a loss of sympathy for financial lobbies, a renewed interest in a "modern" industrial policy, and a powerful critique of the very concept of economic growth from the green and climate-change lobbies.

How this will affect the details of program reductions is difficult to forecast. There might be a greater reluctance to cut budgets that affect training, business support, or procurement. One important issue will be how spending cuts affect the rapid growth in public-private partnerships, outsourcing, and service delivery by the private sector. As regards capital spending in particular, much of the cost is borne by the private sector through the Private Finance Initiative and is not included in official statistics of government debt. Reducing spending may suggest more private delivery, but gaining better control over budgets and value for money may encourage government to bring more services in-house.

In any event, the political debate insists that spending should be assessed in terms of its contribution to growth, which implies limiting the costs to the corporate sector. There is an expectation of a return to normality, which is odd since the last seven years of growth have, by definition, been abnormal. We have seen a lack of political imagination, especially in the context of climate change and sustainability. It might have been thought that a financial crisis would provide an opportunity to tilt the economy and government policy more deliberately towards a steady-state, sustainable economy in which GDP growth receives a lower priority. Such ideas have entered the public domain with increased discussion of the "politics of happiness" (Layard 2005) and alternative indices of well-being (NEF 2009a; Coyle forthcoming), but as yet the main political parties have not been willing to transcend the commitment to economic growth as a dominant aim of economic policy.

Opportunities for radical initiatives: A fundamental shift in spending priorities is inevitable. As in all crises (Boin, 't Hart, and McConnell 2009), this will present opportunities for radical policy innovation. One such innovation would be to allow local authorities and decentralized agencies to make choices about what to cut, perhaps in dialogue with their clientele. This has been advocated by the Liberal Democrats (Cable 2009, 34) and builds on the recognition that many local councils have 
developed impressive performance and delivery records that can be exploited and generalized (see Audit Commission 2009; Lee 2009).

A second innovation would be to encourage the growth of "social enterprise," a third sector of nonprofit voluntary or cooperative organizations that work within multipartner networks to deliver personalized services in areas like care for the elderly, social housing, and mental health (Bartlett 2009). A third would be to use reconfiguration of spending to pursue a green agenda, addressing climate change issues by investing in green infrastructure, "green collar" jobs, and green capitalism as advocated by Barack Obama in the United States and by left-leaning environmentalists in the United Kingdom (NEF, 2009b).

A fourth area, unfortunately almost inconceivable in the British political climate, would be to sacrifice the sacred cow of the NHS. The truly huge public expenditures are personal social services and health care. A move in health care towards a scheme of compulsory insurance, funded by individuals and employees on the Canadian, German, or French model, would have the potential to generate substantial savings. Finally, and this is far more likely, government could abolish universal benefits and make them more targeted and based on need. This was already under discussion by Labor under the rubric of "progressive universalism," and it would target the cross-subsidies enjoyed by the middle classes in the shape of child benefits, student loans, and even the old age pension. To means-test these benefits would be controversial, but here, as in other areas of social service delivery, the devil is in the detail-how these savings are implemented is as important as the changes themselves.

Overall, then, the political agenda has shifted decisively towards a debate over cuts, but the party programs remain inchoate. The party manifestos presented to the public during the spring 2010 election campaign, especially the Conservative manifesto, will condition the conduct of British public administration for the next decade. We have yet to see a distinctive, inspirational vision emerge. Instead, party leaders are very hesitant to be open about the substantial and even savage cuts that all political and economic specialists see as inevitable.

What is truly extraordinary is that the great debate has moved so firmly from market failure to spending cuts. The fact is that the vulnerable in society-the poor, the unemployed, the ill, children, and the elderly - are going to pay a price for the financial crisis. In these circumstances, we might have expected a more determined commitment to a wealth tax, the elimination of large bonuses paid to bankers, a redesign of the financial system, taming of hedge funds and investment banking practices, redesign of corporate governance, a new industrial policy, or a shift to a sustainable society. Sadly, the headlines are all about budget cuts, so how will the British civil service respond? 


\section{ADMINISTRATION UNDER SCARCITY}

It is immensely difficult to make immediate real reductions in public spending. The British government achieved real spending cuts in only six of the past forty-five years (1977, 1985, 1988, 1990, 1996, and 1997-IFS 2009a), and those were small. In the most thorough scholarly account of the control of public spending, Thain and Wright $(1995,2)$ confirmed that "the Thatcher years also show how extraordinarily difficult it was to cut the real level of spending." With this background, the blithe discussion by politicians, think tanks, and the media of where and how much to cut public spending has an air of unreality. The big question is, how can the civil service deliver spending cuts without provoking breakdowns and crises that will negate many of the assumed gains?

We can try to answer this question through three hypotheses based on projected cuts of 5 percent per annum in core budgets (DEL) over the four years of 2011-12 to 2014-15. That would involve cuts of 20 percent in the core budgets of $£ 300$ billion, building up to an annual cut of about $£ 60$ billion after four years, or a cut of almost 10 percent after four years in total public spending of $£ 671$ billion. In other words, the hypotheses are based on a level of cuts in public spending that has no peacetime precedent in the United Kingdom. The three hypotheses concern the likelihood of success; the first is pessimistic, the second optimistic, and the third systemic.

Breakdown hypothesis: The present UK system of government and administration is incapable of delivering the spending reductions.

Managerial hypothesis: The reforms to the public sector associated with the New Public Management (NPM) have equipped the civil service to deliver cuts based on well-articulated political priorities.

Redefinition hypothesis: Implementing cuts will requite a redefinition of collective political-administrative leadership.

\section{The Breakdown Hypothesis}

The apparatus of public administration exists mainly to spend public money-that is what it does. If the supply of money is drastically reduced, it is like turning down the taps in an irrigation system: the crops wither and the harvest fails. The whole process of budgeting and expenditure control is a core activity and a fundamental annual cycle in almost all public organizations. If that cycle is reconfigured, it will have an impact on all administrative activity.

In terms of institutional theory, a major contraction in spending will affect the regu- 
lative, normative, and cognitive constraints that have built up over decades. Public organizations will have to revise their rule systems, redefine acceptable standards, and adjust expectations. The basic activities that make up the job of a senior public servant—such as planning, coordinating, leading, motivating, and organizing-will all have to be redesigned in the face of spending cutbacks. Familiar routines, long-accepted compromises, and common goals will all be destabilized. How do you coordinate with other agencies when you have no resources to contribute? How do you plan for two years ahead when your budget might evaporate? How do you motivate subordinates whose jobs are under threat, whose salaries have been cut, and whose pensions are no longer guaranteed? All these tasks can be achieved, but each has to be achieved differently. The existing civil service machine cannot deliver real expenditure reductions; it has no reverse gear.

Another way of expressing this skepticism is through the theory of the budget maximizing bureaucrat as analyzed by Niskanen (1971) and other exponents of public choice theory. One influential theory of public administration is therefore centered on officials seeking a greater allocation of public spending:

The great appeal of the Niskanen model lies . . . in its capacity to account for the well-established propensity of bureaucrats to seek larger budgets. It does make sense to assume that bureaucrats attempt to maximize their budgets and to make that assumption the central proposition of a theory of bureaucratic behavior. (Blais and Dion 1991, 359).

We can perhaps accept this budget maximizing bias without accepting the entirety of the public choice approach. If we do so, it logically leads to the conclusion that system-wide expenditure cuts are unnatural, like asking doctors to injure patients or teachers to mislead students. A less flattering parallel might be drawn with banking and the explosive issue of bankers' excessive remuneration and bonuses. Just as bankers have been vilified as greedy bonus maximizers, so civil servants may be criticized as greedy budget maximizers, both providing examples of a logical pursuit of individual utility but both producing overall public damage in an unfortunate reversal of Adam Smith's metaphor of the invisible hand. In any event, faced with this predominant behavioral incomprehension and rejection of cuts, the civil service may not disintegrate, but it will certainly fail.

This prognosis of failure is rooted in a rich seam of historical and comparative examples. Canada provided a rare and now widely cited example of success in the mid 1990s, but "between 1984 and 1993 the Government of Canada made a total of 22 budget cuts, each more difficult than the previous and each more demoralizing for the Public Service" (Bourgon 2009, 16). These initial failures were explored by Savoie, 
who reviewed the intense pressures for growth in spending, expressed some sympathy for Niskanen's analysis, and examined the failure of "rational budgeting" devices in the absence of complete political support (Savoie 1990, 335-47).

For the United Kingdom, Thain and Wright developed a theory of "negotiated discretion" to interpret the relationship between the Treasury as the expenditure controller and the spending departments. They concluded that in a domestic spending crisis, "negotiated discretion would become untenable" and "it would be essential to lock the Cabinet and hence individual ministers collectively and individually into a system capable of delivering unpalatable outcomes" (Thain and Wright 1995, 547). A focus on the role of the Treasury as the most powerful department in British government is thus central to the discussion. It has been argued that a greater focus on expenditure control is needed-married, perhaps, with an independent Office of Budget Responsibility to provide transparent validation (Turnbull 2010). Without major organizational and cultural change verging on a paradigm shift, the hypothesis of breakdown and failure presents a dangerous but so far barely recognized challenge to the politicians who hope to achieve unprecedented and eye-watering cuts.

\section{The Managerial Hypothesis}

From a far more optimistic perspective, it can be argued that two decades of public sector management reform have transformed the managerial competence of civil service managers such that real cuts can be defined and implemented. After all, the model has been the private sector, where company recovery and "turnround management" is far less rare. If managers in the public sector can be given clear directions on which objectives to prioritize, and what financial envelope is tolerable, then arguably they are equipped to deliver.

The expectation would be that ministers would define clear priorities, including cutting entire programs. They would prioritize in terms of outcomes (not inputs) and would exploit managerial autonomy and ability by simply allocating a sum of resources to accounting units and authorizing them to achieve outcomes in any legal way within their financial envelope. This approach of "bulk" or "framework" budgeting plays to some of the strengths of the New Public Management, most notably the following:

- Government increasingly operates through discrete units in departments or agencies that have a degree of managerial autonomy and more-or-less empowered managers or boards.

- The focus in policy and expenditure planning has already moved towards the 
definition of general outcomes and away from inputs or even outputs. These were embodied in the thirty Public Service Agreements contained in the 2007 Comprehensive Spending Review, so that the concept of flexible outcome achievement is already familiar.

- Government units have far better information about their budgets and activities than they did even ten years ago. Partly this is a result of the digital revolution, but it also reflects huge strides in government accounting with the development of cost-center accounting, accrual accounting, and financial reporting. Government units can therefore analyze their activities and share that analysis with clients and stakeholders more effectively.

- Performance management has been firmly embedded in local government, in many agencies and central departments. This should provide management with information about what works, what is cost-effective, and what the outcomes would be of reducing or closing expenditure programs.

- Partnerships have become the norm in many service areas. Delivery agencies work with other levels of government, with the voluntary sector, and with private sector service providers. On the one hand, this may make it easier to exit from spending commitments and to close down programs. On the other hand, it may make it possible to transfer responsibilities and to regulate instead of funding certain activities. The whole area of contracting out, of delivering through public service companies and public/private partnerships, is full of both potential and pitfalls.

Cutting public expenditure by relying on the reforms introduced under the NPM would involve the same return to the politics/administration dichotomy that lies at the heart of the NPM. Ministers would set priorities, but in this case they would prioritize what is to be cut. The implementation would be delegated down the managerial hierarchy. This approach could accommodate a policy of "equal misery" with, say, a 10 percent cut in every budget, or it could preserve some programs and eliminate others. The key would be giving up central control and direction of implementation. It would require flexibility over areas such as staffing and contracting out and support for radical initiatives. In this sense, it would be relatively high risk, but it would have the great advantage of more localized decision making, which could reach out to clients, partners, and the public to secure greater understanding of the options for spending cuts.

Could the managers, organizations, and tools created by the NPM rise to the challenge? For some observers, the NPM is part of the problem, not the solution. There is a danger that single-purpose organizations will fight cuts even more determinedly and that the NPM will inhibit the development of collective and collegiate leadership. Recognizing these dangers would be a further challenge for cutback managers, who might have to be prepared to limit agency autonomy or to abolish some agencies entirely. 


\section{The Redefinition Hypothesis}

To avoid the breakdown hypothesis, and to exploit the managerial hypothesis, government at the center will have to be redefined. To achieve real cuts in spending, ministers will have to work together collectively and engage in a creative partnership with senior civil servants. Together they will have to create new procedures, establish new principles, and change expectations towards a new vision. Regaining fiscal sovereignty will have to become a metapolicy—a political obsession.

One widely cited example of a government achieving huge real spending reductions and re-establishing fiscal sovereignty is the case of Canada, which cut real spending by 10 percent in the three years 1994-95 to 1996-97 (Bourgon 2009, 26) and managed to break away from earlier failures to cut spending. Jocelyn Bourgon was head of the Canadian federal civil service from 1994 to 1999, and her account gives a positive civil service view, but one that is consistent with academic studies (Swimmer 1996; Lindquist 2006). Bourgon emphasized transformations in leadership and partnership, and specifically:

- the total commitment of Prime Minister Jean Chretien, leader of the Liberal government, and of Finance Minister Paul Martin

- the cooperative and collective commitment of all ministers

- the partnership between ministers and deputy ministers (senior civil servants)

- a zero-base budgeting assumption but flexibility in devising solutions

- a comprehensive 'program review' approach to all government programs in which nothing was excluded or protected

- the open nature of the exercise, with full consultation and transparency

She celebrated the success of the exercise, with cuts over three years ranging from 50 percent for transport to 3 percent for health care, and the number of federal employees falling from 231,000 in 1994 to 187,000 in 1998. She emphasized the continued benign effects in terms of federal surpluses and concluded, "This Canadian case study is an example of cabinet government at its finest" (Bourgon 2009, 33). But she also identified a paradigmatic shift in the nature of Canadian Federal Government so that "Program Review amounted to a profound realignment of the GoC's role" (Bourgon 2009, 29).

A comparison of this Canadian example to the challenge facing the United Kingdom suggests that three governmental adaptations are essential. First, there should be a return to cabinet government, the deterioration of which, in the practice and the constitutional theory, began under Margaret Thatcher in the 1980s but has deepened under Tony Blair and Gordon Brown. They have developed a presidential, domineering style 
of more personalized and unilateral decision making. The spending challenge will require collective determination, not individual diktat. Individual ministers would need to share a collective commitment to spending reductions and manage their departments with that end in mind and in cooperation with colleagues.

Second, cabinet ministers should rebuild their partnerships with the civil service and especially with their permanent secretaries. Suspicion and even hostility towards the civil service and local government is another legacy of the Thatcher period. Spending cuts will require whole-hearted civil service cooperation and will rely on civil service reservoirs of information, expertise, enterprise, and dedication that are too easily overlooked. This requires trust and a greater degree of mutual respect, which the Cabinet Secretary has sought to promote through public capability reviews of all government departments that have focused on ways of improving the partnership between ministers and civil servants in shared leadership (see Wilks 2007).

Third, the analytical capability and authority of the center of government will have to be enhanced. There has been much discussion of the "hollowing out" of British government, with legitimacy and capacity leaking away to the devolved governments, the EU, independent agencies, and the private sector. Curiously, that hollowing out is less marked in relation to public spending, in which the Treasury remains dominant, but nonetheless, central organization and analytical capacity would have to be strengthened. This would involve supplementing the capacity of the Treasury and extending spending responsibility beyond the expenditure divisions of the Treasury. The Treasury will have to overcome its instinct for detailed control and will have to overcome latent distrust of it by spending departments and ministers. Just as war is too important to be left to the generals, so fiscal consolidation is too important to be left to the Treasury.

\section{BLEEDING STUMPS AND FAIRY GOLD: CUTTING BUDGETS AGAINST ADMINISTRATIVE RESISTANCE}

The initial debates about spending cuts in the UK stressed, first, that efficiency savings would not be adequate to secure sufficient cuts, and second, that "salami-slicing" involving indiscriminate across-the-board cuts should be avoided in favor of a comprehensive reconsideration of governmental priorities. To state the obvious, this means that the "managerial efficiency" response of doing the same things but more efficiently will not be enough, and that a means must be found to prioritize the activities of government.

Some political priorities were discussed above, but the process of converting them into actual cuts, incorporated into operating budgets, is exceedingly difficult. Budget- 
ing in the public sector is famously dominated by incrementalism (Peters 2010, 239), and the familiar ways of making cuts are based on an annual cycle of small increments (or decrements) to existing budgets. Conventional options therefore include equal misery-reducing every budget by the same amount (this is the salami-slicing that politicians reject); cash limits, letting inflation do the work; recruitment freezes, which bring rough justice depending on how departures are clustered; and charging for public services. These options are widely understood and, as Hood and Wright (1981, 203) pointed out, "the equal misery approach may have a very strong element of rationality about it." It can be implemented rapidly, can be applied to the whole spending portfolio, treats everyone equally, and does not require elaborate analysis, horse-trading, and political agonizing.

Not surprisingly, there has been consistent pressure for more rationality and prioritization in budgeting. The available techniques include PPBS (program, planning, budgeting system), ZBB (zero-base budgeting), and the program review approach used in Canada. The United Kingdom has been something of a trailblazer in seeking to plan and prioritize in budgeting. It has developed a system of expenditure surveys, which plan capital and current spending over a three-year time horizon. Under Gordon Brown, the Treasury also introduced methods of identifying and controlling cash and discretionary spending measured by accruals accounting similar to private-sector practices. This whole apparatus has been punctuated by periodic Comprehensive Spending Reviews, the latest of which was in 2007, which have required departments to justify their programs on a ZBB principle and to express them as outcomes rather than inputs. The agreed funding and policy outcomes are then expressed as a series of Public Service Agreements, which provide a mission statement for the department and constitute a widely publicized set of goals and targets for which the department or agency can be held accountable.

The United Kingdom would therefore appear to have effective machinery for controlling public spending, centered on the Treasury and available to deliver cuts. But, to return to the points about administrative behavior raised above, there is a huge literature and a great weight of experience to indicate that there will be immense resistance to cuts. Budget maximization is a plausible goal for ministers as well as civil servants. Their success, status, and power are all related to the size of the budget they control. Their pursuit of extra resources is perfectly understandable. It is not too naive to suggest that people enter politics to make a difference- to help fellow citizens or achieve valued goals. This nearly always requires financial resources, so resistance to cuts is as much a part of the political DNA as it is of administrative behavior.

Implementing spending cuts will therefore be exceedingly difficult, and the skills, techniques, and leadership of cutback management will become highly valued. Cut- 
back managers will need to develop techniques to overcome resistance and will need to approach their task with commitment but also with a healthy dose of skepticism. There are a number of well-tried tactics for avoiding cuts, such as the "bleeding stumps" and "fairy gold" approaches (Dunsire and Hood 1989, 169). The "bleeding stumps" tactic involves offering up for cuts the most precious and popular services, as when the British Foreign Office famously offered up cuts in the BBC World Service. In a similar vein, the NHS might offer to abolish the family doctor, or local authorities might propose charging for nursery education. The exposure of bleeding stumps generates public outrage, politicians recoil, and cuts are avoided. The "fairy gold" tactic involves offering cuts in years two and three of the survey period-cuts that disappear in year three like the gold at the end of a rainbow. The ability of spending departments to pursue cynical tactics to foil cuts is aided by their control over information. Middle managers responsible for defining and implementing programs have a far better sense of what is wasteful or redundant and could be cut, and what is more productive. They are typically hesitant to share that information with senior managers and especially with the Treasury.

The tendency to protect services is reinforced by the imperative to protect staff and clients. It is easy to predict that coalitions will be formed to protect services involving professional public sector workers, their clients, other service providers such as charities and private sector companies, and public sector unions. These coalitions will not be overcome by mere confrontation, and it is interesting that the Canadian cuts were accompanied by an early retirement scheme and early departure incentives so that "large personnel reductions were accomplished with few involuntary departures . . . and without the labor unrest or service interruptions characteristic of other countries' efforts to reduce the size of their public services" (Bourgon 2009, 29).

It can therefore safely be predicted that exceptional measures will become necessary to cut spending in a way that minimizes harm and maximizes creative responses. The Canadian example might be a useful guide for the United Kingdom and others; at the very least, it demonstrates the need for deliberate planning. Cutback management requires careful consideration, planning, organizational changes, and reconfiguration of incentives in a way that entails a paradigmatic shift in the civil service as an institution. For instance, Conservative politicians have speculated on some radical reforms, such as converting schools, agencies or even parts of departments into semiautonomous cooperatives.

If politicians fail to take the lead, the prognosis is gloomy. As this issue went to press, it remained to be seen whether, in the United Kingdom, the tactical considerations of a general election would prevent politicians confronting the scale and impact of real cuts. The temptation, also seen in current debates, is to promise new policies 
involving more rather than less spending. If politicians fail to lead, senior civil servants may need to prepare for the expenditure crisis that seems as certain a prediction as is possible in the social sciences.

\section{CONCLUSIONS}

The political and administrative shapes of the public spending dilemmas are still uncertain. In the United Kingdom, the agenda is still under contestation and will only become clearer with the spending reviews that a new government will have to undertake after the May election. This article offers five conclusions, which are partly a summary of the argument presented here but also a plea for a renewed focus on cutback management as a set of concepts that we badly need to get right.

First, as has been argued here, severe and prolonged real cuts in public spending are far harder to achieve than is recognized in current debates. There is a real risk that attempts to cut will fail and will bring disruption and unnecessary hardship.

Second, effective cuts will require a unified political commitment and a willingness to make very difficult political choices. The process of defining priorities and specifying expenditure reductions is important and will require specialized machinery at the center.

Third, effective cuts will not be made in the face of civil service opposition. A new partnership with the civil service and with agencies and local government will be essential. The managerial hypothesis suggests that the civil service may be far better equipped than in the past to deliver real cuts, but only if it is empowered, motivated, and treated sympathetically when it comes to downsizing.

Fourth, real cuts of this magnitude will require planning on a program basis. Some large spending programs will have to be discontinued or redesigned, and this will require a genuine public debate. Cuts of this magnitude cannot be secured surreptitiously and must reflect a real deliberation about the shape of the economy and the society. As in the Canadian case, this may involve a fundamental reconsideration of the role of government in society.

Finally, and more ambitiously, this public spending crisis offers extraordinary opportunities for creative reform, if parties and politicians have the imagination to seize them, in areas ranging from conceiving a steady-state, sustainable economy to a radical decentralization and empowering of the localities. As Rahm Emanuel, Barack Obama's chief of staff, remarked, "you never want to let a serious crisis go to waste" (Wall Street Journal 2008). Will governments seize this opportunity?

One route available to governments is to recognize and utilize insights from policy 
studies. The analysis above suggests that, at least in the United Kingdom, it is as close to a social science certainty as we can get to predict that historically unprecedented expenditure cuts cannot be made under the present system without unacceptable disruption, inefficiency, and waste. This prediction of virtual chaos is doubly unfortunate given the opportunities also reviewed above to exploit this critical juncture in a creative fashion. Accordingly, the final appeal presented here is to reinvent the subdiscipline of cutback management to identify, evaluate, and recommend mechanisms for making politically rational choices. Some politicians are fond of saying that procedures are irrelevant, machinery is a distraction, and the only thing that matters is results. They are wrong.

\section{REFERENCES}

Audit Commission. 2009. Final score: The impact of comprehensive performance assessment of local government 2002-08. London: Audit Commission.

Bartlett, J. 2009. Getting more for less: Efficiency in the public sector. London: Demos.

Blais, A., and S. Dion. 1991. Conclusion: Are bureaucrats budget maximisers? In A. Blais and S. Dion. Pittsburgh (ed.), The budget maximizing bureaucrat (pp. 96117). PA: University of Pittsburgh Press.

Boin, A., P. 't Hart, and A. McConnell. 2009. Crisis exploitation: Political and policy impacts of framing contests. Journal of European Public Policy 16(1): 81-106.

Bourgon, J. 2009. Program review: The government of Canada's experience eliminating the deficit 1994-99: A Canadian case study. London: Institute for Government.

Cable, V. 2009. Tackling the fiscal crisis: A recovery plan for the UK. London: Reform.

Coyle, D. n.d.. The economics of enough: How to run the economy as if the future mattered. Unpublished manuscript.

Darling, A. 2009. The Callaghan Lecture, Cardiff, September 8.

DTI (Department of Trade and Industry). 2006. Trade union membership 2005. London: Department of Trade and Industry.

Dunsire, A., and C. Hood. 1989. Cutback management in public bureaucracies. Cambridge: Cambridge University Press.

Fingland, L., and S. Bailey. 2008. The EU's stability and growth pact: Its credibility and sustainability. Public Money and Management 28(4): 223-30.

Gamble, A. 2010. The political consequences of the crash. Political Studies Review 8(1): 5-14. 
Hall, P., and R. Taylor. 1996. Political science and the three new institutionalisms. Political Studies 44: 952-73.

Hood, C., and M. Wright, eds. 1981. Big government in hard times. Oxford: Martin Robertson.

IFS (Institute for Fiscal Studies). 2009a. Reactions to budget 2009: Briefing presentation. London: Institute for Fiscal Studies, www.ifs.org.uk. 2009b. Britain's fiscal squeeze: The choices ahead. IFS Briefing Note BN87. London: Institute for Fiscal Studies. 2010. The IFS green budget. London: Institute for Fiscal Studies, February.

Johnson, S. 2009. The quiet coup. The Atlantic, May. www.theatlantic.com/doc/200905/ imf-advice

Krugman, P. 2008. Gordon does good: Has Gordon Brown . . . saved the world financial system? New York Times, 12 October.

Layard, R. 2005. Happiness: Lessons from a new science. London: Allen Lane.

Lee, D.-O. 2009. Central management of local performance: A comparison of England and Korea. $\mathrm{PhD}$ thesis, University of Exeter.

Lindquist, E. 2006. How Ottawa reviews spending: Moving beyond adhocracy? In B. Doern (ed.), How Ottawa spends, 2006-07: In from the cold-the Tory rise and the Liberal demise (pp. 185-207). Montreal: McGill-Queen's University Press.

Mandelson, P. 2009. Speech to Progress event at the London School of Economics, September 9.

Monbiot, G. 2009. One financial meltdown, it seems, is just not enough for Gordon Brown. The Guardian, September 8.

NEF (New Economics Foundation). 2009a. Happy planet index, 2nd edition. London: New Economics Foundation.

2009b. The cuts won't work: The second report of the Green New Deal Group. London: New Economics Foundation.

Niskanen, W. 1971. Bureaucracy and representative government. Chicago: Aldine Atherton.

O'Connor, J. 1973. The fiscal crisis of the state. New York: St. Martin's Press.

Peters, G. 2010. The politics of bureaucracy, 6th edition. Abingdon, UK: Routledge.

Savoie, D. 1990. The politics of public spending in Canada. Toronto: University of Toronto Press.

Skidelsky, R. 2009. Keynes: The return of the master. London: Allen Lane.

Smith, D. 2010. Why Euro's woes should scare us all. Sunday Times, February 14.

Swimmer, G. 1996. An introduction to life under the knife. In G. Swimmer (ed.), How Ottawa spends 1996-97: Life under the knife (pp. 1-37). Ottawa: Carleton University Press. 
Thain, C., and M. Wright. 1995. The Treasury and public spending: The planning and control of public expenditure, 1976-1993. Oxford: Clarendon.

Treasury. 2009a. Public expenditure: Statistical analyses, 2009. London: H. M. Treasury.

. 2009b. Pre-budget report, 2009. London: H. M. Treasury, December.

Turnbull, A. 2010. Six steps to salvage the Treasury. Financial Times, January 11.

Wilkes, G. 2009. A balancing act: Fair solutions to a modern debt crisis. London: Centre Forum.

Wilks, S. 2007. Boardization and corporate governance in the UK as a response to depoliticization and failing accountability. Public Policy and Administration 22(4): 443-60. 